\title{
Hubungan Kualitas Pelayanan Dimensi Servqual dengan Loyalitas Pasien di Poliklinik RSUD Arosuka Tahun 2018
}

\author{
Titen Yasril ${ }^{1}$, Dachriyanus ${ }^{2}$, Harmawati $^{3}$ \\ ${ }^{1}$ Mahasiswa Program Studi Magister Keperawatan Universitas Andalas Padang \\ 2Wakil Rektor Satu Universitas Andalas Padang \\ ${ }^{3}$ Dosen Poltekkes Kemenkes Padang \\ Correspondence email: titten.yasril@yahoo.co.id
}

\begin{abstract}
Abstrak. Kurangnya kunjungan pasien lama yang berulang akan berdampak meningkatnya biaya promosi untuk mendapatkan pasien baru, salah satu cara untuk mempertahankan pasien lama adalah dengan menumbuhkan loyalitas pasien. Sebahagian pasien di RSUD Arosuka masih belum loyal karena datang ke rumah sakit hanya untuk pemeriksaan pertama, selanjutnya pasien pergi ke rumah sakit lain, sebagian pasien belum merekomendasikan rumah sakit kepada orang lain, salah satu faktor yang mempengaruhi loyalitas pasien adalah kualitas pelayanan. Penelitian ini bertujuan untuk mengetahui hubungan kualitas pelayanan dimensi servqual dengan loyalitas pasien di RSUD Arosuka.Jenis penelitian ini adalah cross sectional. Populasi dalam penelitian ini adalah semua pasien yang datang ke poliklinik RSUD Arosuka Tahun 2018, jumlah sampel 203 orang dengan teknik pengambilan sampel proportional random samplingyang dilakukan pada bulan April 2018 dengan analisis yang digunakan adalah uji chi square. Hasil uji statistik didapatkan60,1\% responden tidak loyal, 61,6\% responden menyatakan tangible kurang baik, 37,9\% responden menyatakan reliability kurang baik, 51,2\% responden menyatakan responsive kurang baik, 43,3\% responden menyatakan assurace kurang baik, dan 48,8\% responden menyatakan empaty kurang baik. Terdapat hubungan yang bermakna antara tangible, reliability, responsive, assurance, empaty dengan loyalitas pasien di RSUD Arosuka dengan nilai $p<0,05$ $(p=0,001, p=0,015, p=0,010, p=0,002, p=0,022)$. Tangible merupakan faktor yang paling dominan berhubungan dengan loyalitas pasien. diharapkan direktur membuat kebijakan tentang jam pelayanan, sanksi bagi yang tidak mentaati jam pelayanan, berkoordinasi dengan pemerintah daerah dalam pengadaan transportasi untuk pasien, kabid penujang mendesain ruang tunggu yang nyaman, dan pengadaan kotak saran untuk pasien.
\end{abstract}

Kata kunci: loyalty; servqual; kualitas

Abstract. The lack of repeated visits of old patients will increase the cost of promotion to get new patients, one way to maintain old patients is to grow patient loyalty. Some patients in Arosuka General Hospital are still not loyal because they come to the hospital only for the first examination, then the patient goes to another hospital, some patients have not recommended the hospital to others, one of the factors that influence patient loyalty is the quality of service. This study aims to determine the relationship between service quality servqual dimensions and patient loyalty in Arosuka Hospital. The type of this study is cross sectional. The population in this study were all patients who came to the Arosuka Hospital polyclinic in 2018, a sample of 203 people with a proportional random sampling sampling technique conducted in April 2018 with the analysis used was the chi square test. The statistical test results obtained $60.1 \%$ of respondents not loyal, $61.6 \%$ of respondents stated that tangible was not good, $37.9 \%$ of respondents stated that reliability was not good, $51.2 \%$ of respondents stated that they were less responsive, $43.3 \%$ of respondents said assurace was not good, and $48.8 \%$ of respondents said empaty not good. There is a significant relationship between tangible, reliability, responsive, assurance, empathy and patient loyalty in Arosuka Hospital with a value of $p<0.05$ ( $p=$ $0.001, p=0.015, p=0.010, p=0.002, p=0.022$ ). Tangible is the most dominant factor associated with patient loyalty. It is expected that the director will make a policy on service hours, sanctions for those who do not obey the service hours, coordinate with the local government in procuring transportation for patients, the head of the ward designing a comfortable waiting room, and providing suggestion boxes for patients.

Keywords: loyalty; servqual; quality

\section{PENDAHULUAN}

Indonesia memiliki tiga jenis rumah sakit dengan fungsi yang berbeda-beda. Pertama rumah sakit pemerintah mengembangkan fungsi politis dan sosial, kedua rumah sakit swasta yang berfungsi sosial, sedangkan ketiga adalah rumah sakit swasta yang berorientasi laba (Khasanah, 2010). Rumah sakit umum daerah Arosuka merupakan salah satu rumah sakit pemerintah dengan tipe $\mathrm{C}$ yang letaknya berdekatan dengan rumah sakit pemerintah dan rumah sakit swasta lainnya dengan tipe yang sama.

Adanya berbagai rumah sakit swasta, klinik dan rumah sakit pemerintah sebenarnya berdampak positif bagi pengguna jasa pelayanan rumah sakit yaitu menjadikannya banyak pilihan. Disisi lain kondisi ini menimbulkan persaingan ketat antar rumah sakit yang memaksa untuk saling berlomba menjadi yang terbaik, hal ini dilakukan dalam rangka mendapatkan loyalitas pelanggan (Wadji.dkk, 2015).

Loyalitas merupakan salah satu permasalahan yang menjadi fokus utama bagi seluruh jajaran manajemen pelayanan kesehatan di Indonesia. Seseorang dinyatakan sebagai pasien yang loyal terhadap rumah sakit jika dia dengan suatu komitmen mempercayakan akan jasa rumah sakit di waktu yang akan datang kepada rumah sakit yang sama (Amin, 2016; Albori Ali, 2010).

Pada kenyataan saat ini pasien yang loyal tidak mudah didapatkan, salah satu faktor yang banyak dikeluhkan pasien sehingga mengakibatkan pasien tidak loyal terhadap rumah sakit adalah kualitas pelayanan yang belum sesuai dengan yang diharapkan pasien diantaranya berhubungan dengan jadwal visite dokter yang tidak sesuai, fasilitas fisik gedung rumah sakit, komunikasi antara karyawan rumah sakit dengan 
pasien, prosedur administrasi, dan lain-lain (Khasanah, 2010). Loyalitas pasien yang masih kurang terlihat dengan banyaknya kunjungan pasien baru dibandingkan dengan pasien lama

Hasil wawancara dengan pasien yang sudah berkunjung lebih dari satu kali ke RSUD Arosuka, didapatkan bahwa mereka datang ke RSUD Arosuka disaat terdesaksaja, karena tidak punya cukup waktu untuk pergi ke tempat pelayanan kesehatan lainnya, tetapi disaat mereka punya cukup waktu untuk mencari tempat pelayanan lain mereka tidak datang ke RSUD Arosuka, sebahagian dari pasien menyatakan bahwa mereka selalu memanfaatkan RSUD Arosuka jika mengalami masalah kesehatan tetapi jarang mengajak atau merekomendasikan RSUD Arosuka kepada orang lain.

Hasil survei peneliti di rumah sakit Arosuka kabupaten Solok terkait dengan loyalitas pasien di poliklinik, kunjungan pasien lama yang berulang sangat sedikit dibandingkan dengan kunjungan pasien baru, hal ini terlihat saat dibagian pendaftaran lebih banyak pasien baru yang datang daripada pasien lama. Hasil data yang didapatkan dari bagian rekam medis RSUD Arosuka dari total kunjungan poliklinik tahun 2017 56\% kunjungan merupakan pasien baru, hanya $44 \%$ pasien yang merupakan pasien lama berulang.Data ini terlihat bahwa pasien yang loyal terhadap rumah sakit masih kurang, hal ini akan berdampak semakin menurunnya kunjungan pasien lama sehingga rumah sakit harus mencari pasien baru, tetapi belum bisa untuk mempertahankannya apalagi perkembangan pengetahuan pasien akan meningkatkan kebutuhan pasien terhadap pelayanan.

Kualitas pelayanan merupakan salah satu aspek yang harus diperhatikan oleh rumah sakit karena peningkatan persaingan dalam industri kesehatan yang disebabkan oleh perkembangan teknologi informasi dan kemudahan transportasi sehingga masyarakat memiliki akses yang luas dan alternatif yang banyak untuk memilih rumah sakit yang terbaik dan sesuai dengan kebutuhan mereka. Oleh karena itu, rumah sakit harus memastikan kualitas pelayanan mereka, karena bertanggung jawab terhadap keselamatan dan kesehatan pasien (Gheorghe, Bobocea, 2016).

Kualitas pelayanan kesehatan mencakup dua dimensi yaitu kualitas teknis (kualitas hasil) dan kualitas fungsional (kualitas proses). kualitas teknis berfokus pada keakuratan diagnosa dan prosedur medis sedangkan kualitas fungsional mengacu pada cara layanan perawatan kesehatan yang diberikan pada pasien (Tjiptono, 2012). Karena sebagian besar pasien tidak memiliki pengetahuan yang diperlukan untuk mengevaluasi kualitas teknis layanan, evaluasi kualitas mereka didasarkan pada proses perawatan medis. Untuk mempermudahkan penilaian dan pengukuran kualitas pelayanan dikembangkan model kualitas layanan yang disebut Servqual.

Model servqual memiliki beberapa keunggulan yaitu, pertama servqual telah berkembang menjadi semacam standar untuk penilaian atas berbagai dimensi kualitas layanan, kedua berbagai riset telah menunjukkan bahwa servqual valid dalam berbagai kontex layanan(Tjiptono, 2012).
Servqual dikembangkan oleh Parasuraman, Zeithaml dan Berry semenjak tahun 1985, 1988, 1990, 1991, 1993, 1994 dalam serangkaian penelitian (Tjiptono, 2012). Servqual ini merupakan skala multi item yang dapat digunakan untuk mengukur persepsi pelanggan atas kualitas pelayanan yang meliputi lima dimensi menurut Zeithaml Berry dan Parasuraman. Kolaborasi antara tiga pakar terkemuka kualitas layanan A.Parasuraman, Valaria A. Zeithaml, dan leonard L.Berry mereka memaparkan secara rinci lima dimensi kualitas layanan yang berpotensi menjasi sumber masalah kualitas layanan. Model yang dinamakan servqual ini dikembangkan dengan maksud untuk membantu para manajer dalam menganalisis sumber masalah kualitas dan memahami cara-cara memperbaiki kualitas layanan(Tjiptono, 2012). Kualitas pelayanan model Servqual ini bisa mengidentifikasi persepsi pasien tentang kualitas pelayanan pasien berdasarkan lima atribut yaitutangibel reliability, responsivenes, assurance, dan empathy,(Nekoei Mahmood, 2009; Imroatul, 2010).

Tangibel berwujud berupa penampilan fisik, peralatan, personal, dan komunikasi internal, reliability berupa kemauan membentuk pelayanan yang dijanjikan dengan tepat dan memiliki ketergantungan, responsivenes berupa pertanggungjawaban yakni rasa tanggung jawab terhadap mutu pelayanan, assurance berupa jaminan yaitu pengetahuan, perilaku dan kemampuan pegawai dan empathy yaitu perhatian perorangan pada pelanggan (Riduwan, 2014)

Analisis kualitas pelayanan memungkinkan manajemen rumah sakit mengalokasikan sumber keuangan untuk meningkatkan kinerja di bidang yang memiliki pegaruh lebih besar terhadap persepsi konsumen (Zarei, 2012).

Rumah Sakit dalam mengelola loyalitas pasien harus memahami faktor-faktor yang mempengaruhi loyalitas pasien. Berbagai penelitian yang telah dilakukan oleh Albori,Ali (2010) diperoleh hasil bahwa dari lima dimensi kualitas pelayanan yang sangat berhubungan dengan loyalitas pasien adalah reliability, assurance, dan empathy, sedangkan tangibility dan responsive tidak signifikan dengan loyalitas pasien, Cronin et al (2000) yang menyimpulkan bahwa dimensi assurance mempunyai hubungan dan pengaruh terhadap loyalitas. Aryani (2010) diperoleh hasil bahwa kelima dimensi kualitas pelayanan mempengaruhi loyalitas pasien, Tabibi (2010) diperoleh hasil bahwa ada hubungan yang bermakna antara kualitas pelayanan dengan loyalitas pasien, Hajikhani (2015) diperoleh hasil ada hubungan yang signifikan antara loyalitas dengan dimensi pelayanan, Suki (2011) menyimpulkan ada hubungan antara komitmen pasien dengan loyalitas, Ladhari (2011) menyimpulkan kualitas pelayanan, emosional, kepuasan dan citra merupakan pendorong utama loyalitas, Lonial (2010) menyimpulkan kualitas keseluruhan mempengaruhi niat dan perasaan pelanggan terhadap layanan rumah sakit.

Rumah Sakit Umum Daerah (RSUD) Arosukamerupakan salah satu rumah sakit milik pemerintah daerah Solok Selatan. RSUD Selok Selatan menjadi kelas tipe C.RSUD Arosukamenyediakan pelayanan rawat jalan terdiri dari poliklinik penyakit 
dalam, poliklinik bedah, poliklinik kebidanan, poliklinik anak, poliklinik THT, poliklinik neurologi, poliklinik gigi, poliklinik mata, poliklinik jantung, poliklinik paru.

Hasil wawancara dengan bagian kepegawaian RSUD Arosuka didapatkan data bahwa RSUD Arosuka memiliki 16 orang dr Spesialis (Spesialis bedah, penyakit dalam, anak, kebidanan, radiolologi, anestesi, patologi klinik, mata, THT, kulit kelamin, jantung, paru, syaraf, rehabilitas medik), dokter gigi 2 orang, dokter umum 15 orang, S2 keperawatan 1 orang, S1 keperawatan 13 orang, D3 keperawatan 75 orang, dan SPK 2 orang.

Hasil wawancara dengan 9 orang pasien yang datang ke poliklinik RSUD Arosuka, 6 orang pasien mengatakan bahwa pelayanan belum sesuai dengan yang diharapkannya contohnya dokter memberikan pelayanan belum sesuai dengan jadwal yang telah ditentukan sehingga pasien harus menunggu lama, komunikasi pemberi pelayanan dengan pasien kurang ramah, lokasi rumah sakit jauh dari jalan lintas sehingga susah untuk akses ke luar, tetapi mereka masih memanfaatkan pelayanan rumah sakit untuk mendapatkan pelayanan kesehatan karena rumah sakit arosuka dekat dengan tempat tinggalnya yang memudahkan keluarga untuk mengunjungi. Pasien yang lain mengatakan pelayanan rumah sakit Arosuka sesuai dengan yang diharapkannya, mereka mendapatkan pelayanan yang ramah dari petugas, dimana semua yang dikeluhkan dan ditanyakan oleh pasien bisa dijelaskan oleh petugas sehingga pasien selalu ke rumah sakit Arosuka jika mengalami gangguan kesehatan.

Berdasarkanlatarbelakang

yang telahdiuraikandiatas, perlu kiranya dilakukan maka penelitian dengan judul "hubungan kualitas pelayanan dimensi servqual dengan loyalitas pasien di rawat jalan Rumah Sakit Umum Daerah Arosuka tahun 2018"

\section{METODE PENELITIAN}

Penelitian ini adalah penelitian yang dilakukan dengan pendekatan kuantitatif, karena informasi data yang diperoleh, disajikan dalam bentuk angka-angka dan dianalisis dengan menggunakan analisis statistik. Penelitian ini merupakan penelitian korelasi dengan pendekatan cross sectional yang merupakan rancangan penelitian dengan melakukan pengukuran atau pengamatan pada saat bersamaan, yang didalamnya terdapat analisis hubungan dan membutuhkan jawaban dengan menggunakan analisis statistik ( Alimul 2009). Hasil yang diharapkan dapat diketahui antara hubungan kualitas pelayanan dimensi servqual dengan loyalitas responden di RSUD Arosuka tahun 2018.

\section{HASIL DAN PEMBAHASAN}

RSUD Arosuka adalah salah satu rumah sakit milik pemerintah Kabupaten Solok dan merupakan rumah sakit tipe $\mathbf{C}$. Rumah sakit ini sudah diregistrasi semenjak 25 Desember 2009 dengan Nomor Surat izin 800/419/Dinkes/2010 dan Tanggal Surat izin 04/01/2010 dari Bupati Solok. Setelah mengikuti proses akreditasi rumah sakit seluruh Indonesia dengan 5 Pelayanan, akhirnya diberikan status lulus akreditasi rumah sakit. Rumah sakit umum ini berlokasi di Jl. Lintas Sumatera Arosuka, Kabupaten Solok Indonesia.

\section{Loyalitas}

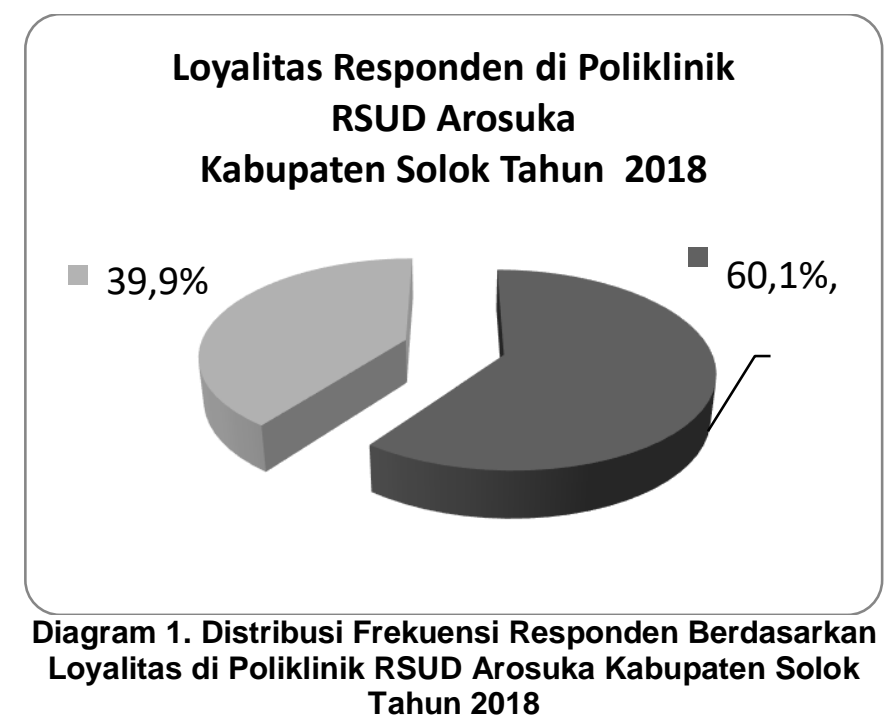

Berdasarkan grafik pie pada gambar di atas dapat dilihat bahwa lebih dari separuh $(60,1 \%)$ responden yang tidak memiliki loyalitas di poliklinik RSUD Arosuka Kabupaten Solok tahun 2018.

\section{Kualitas Pelayanan (Dimensi Servqual)}

Tabel 1. Distribusi Frekuensi Responden Berdasarkan Kualitas Pelayanan di Poliklinik RSUD Arosuka Kabupaten Solok Tahun 2018

\begin{tabular}{cccc}
\hline Variabel & Kategori & F & $\%$ \\
\hline \multirow{2}{*}{ Tangible } & Kurang Baik & 125 & 61.6 \\
& Baik & 78 & 38.4 \\
Reliability & Kurang Baik & 77 & 37.9 \\
& Baik & 126 & 62.1 \\
Responsive & Kurang Baik & 104 & 51.2 \\
& Baik & 99 & 48.8 \\
Assurance & Kurang Baik & 88 & 43.3 \\
& Baik & 115 & 56.7 \\
Empati & Kurang Baik & 99 & 48.8 \\
& Baik & 104 & 51.2 \\
\hline
\end{tabular}

Berdasarkan tabel 1 diketahui bahwa lebih dari separuh $(61,6 \%)$ responden yang berkunjung menyatakan bahwa tampilan fisik rumah sakit kurang baik di Poliklinik RSUD Arosuka Kabupaten Solok tahun 2018. Kemudian lebih separuh (62.1\%) responden yang berkunjung menyatakan bahwa kehandalan petugas baik di poliklinik RSUD Arosuka Kabupaten Solok Tahun 2018. Selanjutnya lebih dari separuh $(51,2 \%)$ responden menyatakan bahwa daya tanggap petugas kurang baik di poliklinik RSUD Arosuka Kabupaten Solok Tahun 2018. Selain itu juga diketahui bahwa hampir separuh (43.3\%) responden yang berkunjung menyatakan bahwa jaminan pelayanan kurang baik di poliklinik RSUD Arosuka Kabupaten Solok Tahun 2018. Kemudian hampir separuh (48,8\%) responden yang berkunjung menyatakan bahwa empati petugas kurang baik di poliklinik RSUD Arosuka Kabupaten Solok Tahun 2018. 


\section{Analisa Bivariat}

Tabel 2. Distribusi Frekuensi Hubungan Kualitas Pelayanan (Dimensi Servqual) dan Loyalitas Responden di RSUD Arosuka Kabupaten Solok Tahun 2018

\begin{tabular}{|c|c|c|c|c|c|c|c|c|c|}
\hline \multicolumn{10}{|c|}{ Loyalit } \\
\hline \multirow{2}{*}{ Variabel } & \multirow{2}{*}{ Kategori } & \multicolumn{2}{|c|}{ Tidak Loyal } & \multicolumn{2}{|c|}{ Loyal } & \multicolumn{2}{|c|}{ Total } & \multirow{2}{*}{$p$ - value } & \multirow{2}{*}{$\begin{array}{c}\text { OR } \\
95 \% \mathrm{Cl}\end{array}$} \\
\hline & & $\begin{array}{c}n \\
122\end{array}$ & $\begin{array}{c}\% \\
60,1\end{array}$ & $\begin{array}{c}n \\
81\end{array}$ & $\begin{array}{c}\% \\
39,9\end{array}$ & $\begin{array}{c}f \\
203\end{array}$ & $\begin{array}{c}\% \\
100\end{array}$ & & \\
\hline \multirow{2}{*}{ Tangible } & Kurang Baik & 87 & 69,6 & 38 & 30,4 & 125 & 100 & \multirow{2}{*}{0,001} & 2.813 \\
\hline & Baik & 35 & 44,9 & 43 & 55,1 & 78 & 100 & & $(1.564-5.058)$ \\
\hline \multirow{2}{*}{ Reliability } & Kurang Baik & 55 & 71,4 & 22 & 28,6 & 77 & 100 & \multirow{2}{*}{0,015} & 2.201 \\
\hline & Baik & 67 & 53,2 & 59 & 46,8 & 126 & 100 & & $(1.201-4.034)$ \\
\hline \multirow{2}{*}{ Responsive } & Kurang Baik & 72 & 69,2 & 32 & 30,8 & 104 & 100 & \multirow{2}{*}{0,010} & 2.205 \\
\hline & Baik & 50 & 50,5 & 49 & 49,5 & 99 & 100 & & $(1.243-3.912)$ \\
\hline \multirow{2}{*}{ Assurance } & Kurang Baik & 64 & 72,7 & 24 & 27,3 & 88 & 100 & \multirow{2}{*}{0,002} & 2.621 \\
\hline & Baik & 58 & 50,4 & 57 & 49,6 & 115 & 100 & & $(1.446-4.750)$ \\
\hline \multirow{2}{*}{ Empati } & Kurang Baik & 68 & 68,7 & 31 & 31,3 & 99 & 100 & \multirow{2}{*}{0,022} & 2.031 \\
\hline & Baik & 54 & 51,9 & 50 & 48,1 & 104 & 100 & & $(1.145-3.602)$ \\
\hline
\end{tabular}

\section{Hubungan Tampilan Fisik (Tangible) dengan Loyalitas Responden}

Hasil penelitian tentang hubungan tampilan fisik dengan loyalitas responden yang berkunjung di RSUD Arosuka Kabupaten Solok Tahun 2018 dapat dilihat pada Tabel 5.4 bahwa proporsi loyalitas responden yang tidak loyal lebih besar pada tampilan fisik (tangible) yang kurang baik $(69,6 \%)$ dibanding responden yang loyal hanya sebanyak 38 orang saja $(30,4 \%)$.

Hasil uji statistik dengan menggunakan uji chisquare didapat nilai $p$-value $0,001<0,05$, artinya terdapat hubungan yang bermakna antara tampilan fisik (tangible) dengan loyalitas responden di Poliklinik RSUD Arosuka Kabupaten Solok Tahun 2018.

Dari hasil analisis peluang ditemukan nilai $\mathrm{OR}=$ 2,813 artinya tampilan fisik (tangible) yang baik mempunyai peluang 2,813 kali untuk meningkatkan loyalitas responden di Poliklinik RSUD Arosuka Kabupaten Solok Tahun 2018 dibandingkan tampilan fisik (tangible) yang tidak baik.

\section{Hubungan Kehandalan (Reliability) dengan Loyalitas Responden}

Hasil penelitian tentang hubungan kehandalan dengan loyalitas responden yang berkunjung di RSUD Arosuka Kabupaten Solok Tahun 2018 jika dilihat pada Tabel 5.4 terlihat bahwa proporsi loyalitas responden yang tidak loyal lebih besar pada kehandalan (reliability) yang kurang baik $(71,4 \%)$ dibanding responden yang loyal $(28,6 \%)$.

Hasil Uji statistik dengan menggunakan uji chisquare didapat nilai $p$-value $0,015<0,05$, artinya terdapat hubungan yang bermakna antara kehandalan (reliability) dengan loyalitas responden di poliklinik RSUD Arosuka Kabupaten Solok Tahun 2018.

Dari hasil analisis peluang ditemukan nilai $\mathrm{OR}=$ 2,201 artinya kehandalan yang baik mempunyai peluang 2,201 kali untuk meningkatkan loyalitas responden di Poliklinik RSUD Arosuka Kabupaten Solok Tahun 2018 dibandingkan kehandalan yang tidak baik.

\section{Hubungan Daya Tanggap (Responsive) dengan Loyalitas Responden}

Hasil penelitian tentang hubungan daya tanggap dengan loyalitas responden yang berkunjung di RSUD Arosuka Kabupaten Solok Tahun 2018 jika dilihat dari Tabel 5.4 bahwa proporsi loyalitas responden yang tidak loyal lebih besar pada daya tanggap (responsive) yang kurang baik $(69,2 \%)$ dibanding responden yang loyal hanya $(30,8 \%)$.

Hasil uji statistik dengan menggunakan uji chisquare didapat nilai $p$-value $0,010<0,05$, artinya terdapat hubungan yang bermakna antara daya tanggap (responsive) dengan loyalitas pasien di Poliklinik RSUD Arosuka Kabupaten Solok Tahun 2018.

Dari hasil analisis peluang ditemukan nilai $O R=$ 2,205 artinya daya tanggap yang baik mempunyai peluang 2,205 kali untuk meningkatkan loyalitas pasien di Poliklinik RSUD Arosuka Kabupaten Solok Tahun 2018 dibandingkan daya tanggap yang tidak baik.

\section{Hubungan Jaminan (Assurance) dengan Loyalitas Responden}

Hasil penelitian tentang hubungan jaminan dengan loyalitas responden yang berkunjung di RSUD Arosuka Kabupaten Solok Tahun 2018 jika dilihat dari Tabel 5.4 yaitu bahwa proporsi loyalitas responden yang tidak loyal lebih besar pada jaminan (assurance) yang kurang baik $(72,7 \%)$ dibanding responden yang loyal $(27,3 \%)$.

Hasil uji statistik dengan menggunakan uji chisquare didapat nilai $p$-value $0,002<0,05$, artinya terdapat hubungan yang bermakna antara jaminan (assurance) dengan loyalitas responden di poliklinik RSUD Arosuka Kabupaten Solok Tahun 2018.

Dari hasil analisis peluang ditemukan nilai $O R=$ 2,621 artinya jaminan yang baik mempunyai peluang 2,621 kali untuk meningkatkan loyalitas pasien di Poliklinik RSUD Arosuka Kabupaten Solok Tahun 2018 dibandingkan jaminan yang tidak baik.

\section{Hubungan Empati dengan Loyalitas Responden}

Hasil penelitian tentang hubungan empati dengan loyalitas responden yang berkunjung di poliklinik RSUD Arosuka Kabupaten Solok Tahun 2018 apabila dilihat dari Tabel 5.3 adalah bahwa proporsi loyalitas 
responden yang tidak loyal lebih besar pada empati yang kurang baik $(68,7 \%)$ dibanding responden yang loyal $(31,3 \%)$.

Hasil uji statistik dengan menggunakan uji chisquare didapat nilai $p$-value $0,022<0,05$, artinya terdapat hubungan yang bermakna antara empati dengan loyalitas responden di poliklinik RSUD Arosuka Kabupaten Solok Tahun 2018.

Dari hasil analisis peluang ditemukan nilai $\mathrm{OR}=$ 2,031 artinya empati yang baik mempunyai peluang 2,031 kali untuk meningkatkan loyalitas responden di Poliklinik RSUD Arosuka Kabupaten Solok Tahun 2018 dibandingkan empati yang tidak baik.

\section{Analisis Multivariat}

Tabel 3. Hasil Seleksi Uji Bivariat Hubungan Kualitas Pelayanan Dimensi Servqual Dengan Loyalitas Responden di RSUD Arosuka Tahun 2018

\begin{tabular}{ll}
\hline Variabel & P-value \\
\hline Tampilan Fisik & 0,001 \\
Kehandalan & 0,015 \\
Daya Tanggap & 0,010 \\
Jaminan & 0,002 \\
Empati & 0,022
\end{tabular}

Pada tabel diatas terlihat bahwa kelima variabel tersebut memiliki nilai $p$ value $<0,25$ dan dimasukkan dalam pemodelan selanjutnya dilakukan uji multivariat menggunakan regresi logistic dengan metode bakcware $L R$, sehingga didapatkan hasil sebagai berikut:

Tabel 4. Pemodelan Multivariat Kualitas Pelayanan Dimensi Servqual Dengan Loyalitas Responden di RSUD Arosuka

\begin{tabular}{|c|c|c|c|}
\hline \multicolumn{4}{|c|}{ Tahun 2018} \\
\hline Variabel & Model 1 p-value & Model 2 p-value & Model 3 p- value \\
\hline Tangibel & 0,021 & 0,020 & 0,009 \\
\hline Reliability & 0,497 & - & - \\
\hline Responsive & 0,241 & 0,214 & - \\
\hline Assurance & 0,081 & 0,064 & 0,032 \\
\hline Empaty & 0,366 & 0,088 & 0,068 \\
\hline
\end{tabular}

Berdasarkan tabel 4 dapat dilihat proses analisis regresi logistik pada kualitas pelayanan dimensi servqual. Pada kualitas pelayanan ditemukan tiga langkah model multivariat, dimana pada dua langkah sebelumnya masih ditemukan variabel dengan $p$-value
$>0,05$ sehingga harus dikeluarkan satu persatu dimulai dari nilai $p$ value yang lebih besar. Pada akhirnya akan terbentuk model akhir multivariat yang akan digambarkan sebagai berikut:

Tabel 5. Hasil Akhir Pemodelan Multivariat Kualitas Pelayanan Dimensi Servqual dengan Loyalitas Responden di RSUD Arosuka Tahun 2018

\begin{tabular}{ccccc}
\hline Variabel & Koefisien & P value & OR & 95\% Cl \\
\hline Tangibel & 0,815 & 0,009 & 2.259 & $1.223-4.175$ \\
Assurance & 0,684 & 0,032 & 1.982 & $1.059-3.708$ \\
Empaty & 0,559 & 0,068 & 1.748 & $0.959-3.188$ \\
\hline
\end{tabular}

Berdasarkan tabel 5 dapat diketahui bahwa variabel yang mempengaruhi loyalitas pasien adalah tangibel, assurance dan empaty. Variabel yang diduga memiliki hubungan paling kuat dengan loyalitas pasien adalah tangibel dengan $p$ value $0,009<0,05$. Nilai $O R$ pada variabel tangibel 2.259 yang artinya adalah tangibel mempunyai peluang 2 kali menyebabkan pasien tidak loyal terhadap rumah sakit dengan $95 \% \mathrm{Cl}$ (1.2234.175).

\section{Pembahasan}

\section{Loyalitas Pasien Rawat Jalan}

Berdasarkan hasil penelitian ditemukan lebih banyak pasien yang menyatakan tidak loyal terhadap rumah sakit. Ini berarti bahwa pasien belum memiliki komitmen untuk setia berobat ke rumah sakit serta memberikan saran kepada orang lain untuk memanfaatkan fasilitas kesehatan di RSUD Arosuka. Hal ini sesuai dengan hasil survei awal yang peneliti lakukan di RSUD Arosuka sebelum melakukan penelitian bahwa kunjungan pasien lama yang berulang sangat sedikit dibandingkan dengan pasien baru.

Penelitian ini sesuai dengan hasil penelitian Fitri, Najmah (2016) tentang hubungan kualitas pelayanan dengan loyalitas pasien di instalasi rawat jalan rumah sakit khusus mata provinsi sumatera selatan dimana hasil penelitian menunjukan bahwa loyalitas konsumen masih rendah yaitu $46.2 \%$, artinya ada sekitar 53,8 pasien yang tidak loyal.

Delgado (2001) menyatakan bahwa loyalitas pelanggan atau customer loyalty adalah sebuah ukuran keterkaitan konsumen terhadap suatu produk yang terwujud pada suatu keinginan untuk membeli ulang dan keinginan untuk merekomendasikan kepada orang lain. Zeithaml (1998) yang dikutip dalam Djohan (2015) juga menyatakan loyalitas adalah pelanggan yang tidak beralih ke rumah sakit lain, rasa memiliki, rekomendasi kepada pihak lain, komitmen, mau bekerjasama dan keakraban.

Responden masih kurang menyarankan serta merekomendasikan orang lain untuk memanfaatkan pelayanan kesehatan di RSUD Arosuka (48,3\%) dan masih ada responden yang belum menetapkan komitmennya untuk berobat di RSUD Arosuka (22,7\%) artinya rasa memiliki, kepercayaan dan keyakinan responden terhadap RSUD Arosuka belum ada, ini terbukti dengan masih kurangnya perilaku responden mengajak orang lain untuk memanfaatkan RSUD Arosuka. Rekomendasi responden kepada orang lain agar memanfaatkan pelayanan kesehatan di RSUD Arosuka sangat cepat diterima orang lain untuk memilih tempat pelayanan kesehatan, sedangkan pasien di 
RSUD sangat jarang merekomendasikan RSUD Arosuka kepada orang lain.

Dari fenomena di atas maka dapat disimpulkan bahwa pada umumnya responden hanya bertahan pada tradisi keluarga yang sudah menggunakan RSUD Arosuka sebagai tujuan utama untuk berobat apabila sakit, hanya memberi saran apabila ada yang bertanya dan hanya menceritakan tentang semua kebaikan tanpa mengajak atau merekomendasikan, bahkan beberapa dari anggota keluarga responden juga sudah tidak banyak yang berobat di RSUD Arosuka. fenomena ini akan menyebabkan rumah sakit perlahan-lahan akan kehilangan pasien lama yang loyalitasnya kurang, sehingga harus mencari pasien baru. Kehilangan pasien lama akan menyebabkan kerugian lebih banyak bagi rumah sakit daripada mempertahankan pasien lama (Zarei, 2012).

\section{Tampilan Fisik (Tangible) Poliklinik RSUD Aro Suka}

Tampilan fisik dalam penelitian ini adalah penilaian pasien terhadap kemampuan rumah sakit yang berkaitan dengan perlengkapan yang dimiliki, ketersediaan tenaga medis, penunjang medis dan non medis yang ada, ruang konsultasi yang nyaman, fasilitas yang memadai, dan kenyamanan selama berobat rawat jalan.

Hasil distribusi frekuensi tentang tampilan fisik rumah sakit menunjukan bahwa lebih dari separuh $(61,6 \%)$ pasien yang berkunjung ke Poliklinik RSUD Arosuka menyatakan bahwa tampilan fisik dari RSUD Arosuka kurang baik, artinya kemampuan rumah sakit yang berkaitan dengan perlengkapan yang dimiliki, ketersediaan tenaga medis, penunjang medis dan non medis yang ada, ruang konsultasi yang nyaman, fasilitas yang memadai, dan kenyamanan selama berobat rawat jalan dalam penilaian pasien masih kurang baik.

Lebih dari separoh responden (75,4\%) menyatakan bahwa tenaga dokter spesialis relatif lengkap di RSUD Arosuka artinya setiap poliklinik yang tersedia di RSUD Arosuka mempunyai dokter spesialis yang lengkap dan siap melayani pasian setiap jam kerja. Berdasarkan Permenkes RI No 56 tahun 2014 tentang klasifikasi dan perizinan rumah sakit dinyatakan rumah sakit tipe $C$ harus memiliki dua dokter spesialis untuk setiap jenis pelayanan medik spesialis dasar meliputi spesialis penyakit dalam, kesehatan anak, bedah, obstetri dan ginekologi dan satu dokter spesialis penunjang meliputi pelayanan anestesi, radiologi dan patologi klinik. Tuntutan akreditasi terhadap rumah sakit tipe $\mathrm{C}$ harus diikuti oleh rumah sakit yang bersangkutan sehingga rumah sakit terus berusaha meningkatkan jumlah dokter spesialisnya.

Dalam penelitian ini hampir separoh responden menyatakan bahwa ruang tunggu masih kurang nyaman $(49,8 \%)$, ruang tunggu merupakan suatu tempat yang harus disiapkan senyaman mungkin karena menunggu merupakan hal yang paling membosankan apalagi menunggu dalam keadaan tubuh yang tidak sehat. Hasil observasi di ruang tunggu poliklinik terlihat ada beberapa kursi tetapi belum mencukupi untuk semua pasien yang datang di poliklinik, ruang tunggu dalam menunggu antrian pendaftaran juga belum tertata dengan bagus karena merupakan jalur buat pasien keluar masuk poliklinik.

Ruang tunggu yang kurang nyaman akan menyebabkan keluhan dari responden terhadap rumah sakit sehingga akan mengurangi loyalitas responden terhadap rumah sakit. Banyak faktor yang menyebabkan ruang tunggu menjadi tidak nyaman, diantaranya proses menunggu pelayanan kesehatan yang lama setelah selesai melakukan pendaftaran dan administrasi, ketersediaan tempat duduk yang kurang sehingga sebahagian pasian dan keluarga harus berdiri sambil menunggu dokter, tata ruangan tunggu yang kurang baik, ventilasi yang kurang, itulah sebabnya banyak rumah sakit terus berupaya melakukan yang terbaik untuk lebih mengatur jadwal kunjungan poliklinik agar pasien tidak menunggu terlalu lama.

\section{Kehandalan (Reliability) Rawat Jalan RSUD Aro Suka}

Kehandalan dalam penelitian ini merupakan penilaian pasien terhadap kemampuan rumah sakit dengan ketepatan waktu pelayanan, waktu untuk mengurus pendaftaran, waktu mulai pengobatan, waktu mengakhiri pengobatan, kesesuaian antara harapan dan reliasasi waktu bagi pasien.

Hasil penelitian tentang kehandalan petugas didapatkan Lebih dari separuh (62.1\%) pasien yang berkunjung ke Poliklinik RSUD Arosuka Kabupaten Solok menyatakan bahwa kehandalan Poliklinik RSUD Arosuka baik. ini berarti masih ada $37.9 \%$ responden menyatakan bahwa ketepatan waktu pelayanan, waktu untuk mengurus pendaftaran, waktu mulai pengobatan, waktu mengakhiri pengobatan, kesesuaian antara harapan dan reliasasi waktu bagi pasien kurang baik.

Parasuraman, Zeithaml dan Berry, 1998 dikutip dari Imroatul (2010) menyatakan bahwa kehandalan merupakan kemampuan perusahaan untuk memberikan pelayanan sesuai dengan apa yang dijanjikan secara akurat, memuaskan dan terpercaya. Pengukuran perilaku (Behavior Measurement), pendekatan ini merupakan hasil dari proses psychology. Perilaku pelanggan yang merasa apa yang didapatkan sesuai dengan harapan atas kinerja perusahaan akan menyampaikan perasaannya itu kepada orang lain (pengaruh dari mulut ke mulut atau word of mouth communication), hal ini akan mendorong terbentuknya loyalitas.

Hasil penelitian ini juga mendukung pendapat Parasuraman et al. (1994) didalam Gunawan (2011) yang menyatakan bahwa perlu ada kesesuaian antara pelayanan medis yang diberikan dengan apa yang dibutuhkan dari waktu ke waktu dan juga pendapat dari Zeithaml (2002), bahwa kehandalan adalah kemampuan untuk memberikan pelayanan yang dijanjikan dengan segera, akurat dan memuaskan. Kehandalan pelayanan adalah kemampuan untuk memberikan secara tepat dan benar jenis pelayanan yang telah dijanjikan kepada konsemen atau pelanggan.

Responden pada umumnya (68\%) menyatakan bahwa petugas pendaftaran datang sesuai dengan jadwal yang ditentukan, artinya pasien yang datang pagi bisa langsung mendapatkan pelayanan dari bagian pendaftaran tanpa harus menunggu, kemudian kebanyakan $(67,5 \%)$ dari reponden juga menyatakan 
bahwa jadwal pelayanan poliklinik dimulai sesuai dengan jadwal yang telah ditentukan, artinya responden setelah melakukan pendaftaran bisa langsung ke ruangan poliklinik yang dituju dan langsng diterima oleh perawat yang bertugas di ruangan poliklinik.

$62,1 \%$ responden menyatakan dokter sudah datang sesuai dengan jadwal yang ditentukan, tetapi masih terdapat $37,9 \%$ responden menyatakan bahwa dokter tidak datang sesuai dengan jadwal pelayanan sehingga menimbulkan keluhan pasien berupa waktu yang dihabiskan untuk mendapatkan pelayanan belum sesuai dengan harapan pasien $(49,8 \%)$ artinya pasien atau keluarga pasien mengeluhkan masalah lamanya waktu yang dihabiskan untuk mendapatkan pelayanan, sehingga pasien cenderung jenuh untuk menunggu, sebagaimana penelitian yang dilakukan oleh Pradana (2014) tentang hubungan lama waktu tunggu dengan persepsi klien terhadap loyalitas dimana responden yang memiliki waktu tunggu lebih cepat memiliki loyalitas cenderung baik dan sebaliknya.

\section{Daya Tanggap (Respensiveness) Rawat Jalan RSUD Arosuka}

Dalam penelitian ini daya tanggap adalah keinginan petugas untuk membantu pasien dan memberikan pelayanan dengan cepat dan tepat kepada pasien dan menyampaikan informasi yang jelas kepada pasien. Hasil penelitian menunjukan bahwa lebih dari separuh $(51,2 \%)$ pasien yang berkunjung menyatakan bahwa daya tanggap (responsive) dari petugas Poliklinik RSUD Arosuka kurang baik. Ini berarti masih kurangnya kesediaan dan kemampuan petugas membantu dan merespon permintaan, keluhan dan menginformasikan jasa yang akan diberikan kepada pasien.

Zeithaml dan Barry (1988) dalam Tjiptono (2012) menyatakan bahwa daya tanggap berkenaan dengan kesediaan dan kemampuan para karyawan untuk membantu para konsumen dan merespon permintaan mereka, serta menginformasikan kapan jasa akan diberikan dan kemudian memberikan jasa secara cepat, membantu para pelanggan dan merespon permintaan mereka dengan segera. Dimensi ini adalah dimensi yang paling dinamis. Harapan konsumen hampir dapat dipastikan akan berubah seiring dengan kecepatan daya tanggap dari pemberi jasa.

Hasil penelitian dari kuesioner pernyataan pasien tentang daya tanggap petugas di RSUD Arosuka yang paling kurang $(49,8 \%)$ adalah perawat yang bertugas menjelaskan kegiatan pelayanan yang akan didapatkan oleh pasien serta menyapa pasien dengan baik dan sopan, artinya perawat yang bertugas belum melakukan interaksi dan komunikasi yang baik kepada pasien dengan menjelaskan semua kegiatan pelayanan yang akan diterima pasien. Sikap perawat yang kurang mengkomunikasikan kegiatan pelayanan yang akan diterima oleh pasien menyebabkan pasien kurang mengerti prosedur pelayanan yang harus dilalui oleh pasien, kalau pasien sudah memahami prosedur setiap kegiatan pelayanan yang akan didapatkan oleh pasien, maka pasien akan mengerti dan memahami sehingga akan mengurangi perasaan ketidakpuasan terhadap lamanya waktu tunggu serta pelayanan yang akan dia terima misalnya seperti prosedur perawatan luka, berbagai pemeriksaan misalnya rontgen dan labor yang mendukung informasi penyakit pasien sehingga pasien harus mempunyai waktu lebih untuk mendapatkan pelayanan.

\section{Jaminan (Assurance) Rawat Jalan RSUD Arosuka}

Jaminan dalam penelitian ini adalah penilaian pasien terhadap kemampuan rumah sakit yang berkaitan dengan kemampuan, pengetahuan, jaminan keamanan, jaminan keselamatan, perilaku petugas yang baik. Dari hasil penelitian didapatkan bahwa hampir separuh pasien (43.3\%) yang berkunjung ke Poliklinik RSUD Arosuka menyatakan bahwa jaminan (Assurance) masih kurang baik. Ini berarti bahwa kemampuan rumah sakit yang berkaitan dengan kemampuan dan pengetahuan, jaminan keamanan, jaminan keselamatan, perilaku petugas yang baik dalam pandangan pasien yang berkunjung ke Poliklinik RSUD Arosuka masih kurang baik.

Satu hal yang sangat terjamin di RSUD Arosuka adalah dokter menjawab pertanyaan pasien yang berkaitan dengan penyakit pasien dan dijawab dengan baik oleh dokter yang bertugas $(75,4 \%)$, artinya pasien merasa yakin untuk memanfaatkan RSUD Arosuka sebagai tempat pelayanan kesehatan karena semua pertanyaan pasien bisa dijelaskan oleh dokter dengan baik. Penelitian ini sama seperti yang dikemukakan oleh Hunt (1998) dalam Seymus Baloglu (2002), bahwa kunci dari relationship marketing adalah hubungan kepercayaan kepada perusahaan sehingga akan melakukan pembelian ulang.

Pernyataan tentang jaminan yang masih kurang adalah semua perawat di poliklinik secara konsisten bersikap sopan kepada pasien maupun keluarga pasien $(49,8 \%)$ dan masalah keamanan dari petugas keamanan $(39,9 \%)$, artinya reponden masih kurang merasakan jaminan dari sikap perawat yang belum bersikap sopan kepada pasien dan petugas keamanan, hal ini akan mengakibatkan pasien merasa hati hati dan tidak nyaman selama berada di rumah sakit. Menurut Hanafi (2004) dalam Fattah (2016) ada dua faktor yang mempengaruhi kualitas jasa pelayanan atas jaminan yang dirasakan pasien yaitu expected service dan perceived service. Apabila pelayanan yang diterima atau dirasakan dapat menjamin pasien, maka kualitas jasa pelayanan akan dipersepsikan sesuai dengan harapan atau baik dan memuaskan jika jasa yang diterima mampu melampaui harapan pasien dan sebaliknya. Oleh karena itu baik tidaknya kualitas pelayanan tergantung pada kemampuan penyediaan jasa pelayanan dalam memenuhi harapan pasien secara konsisten. Pernyataan-pernyataan tersebut tentu menjadi catatan bagi RSUD Arosuka agar lebih meningkatkan faktor-faktor atau instrumen yang berkaitan dengan jaminan terhadap pasien dalam berobat di RSUD Arosuka.

\section{Empati Petugas Rawat Jalan RSUD Arosuka}

Empati dalam penelitian ini merupakan penilaian pasien terhadap kemampuan rumah sakit yang berkaitan dengan kemudahan dalam pencapaian lokasi, kemudahan dalam mengurus administrasi, pengertian 
dan pemahaman petugas, perhatian tinggi dari petugas. Dari hasil penelitian diketahui bahwa hampir separuh (48,8\%) pasien yang berkunjung ke Poliklinik RSUD Arosuka menyatakan bahwa empati petugas kurang baik, ini berarti pasien menganggap bahwa kemudahan dalam pencapaian lokasi, kemudahan dalam mengurus administrasi, pengertian dan pemahaman petugas, perhatian tinggi dari petugas kurang baik dimata pasien yang berkunjung ke RSUD Arosuka.

Sebagaimana dikatakan oleh Imroatul (2010) dalam Nursalam (2013) bahwa empati dalam suatu pelayanan adalah adanya suatu perhatian, keseriusan, simpatik, pengertian dan keterlibatan pihak pihak yang berkepentingan dengan pelayanan untuk mengembangkan dan melakukan aktivitas pelayanan sesuai dengan tingkat pengertian dan pemahaman dari masing-masing pihak tersebut. Pihak yang memberi pelayanan harus memiliki empati memahami masalah dari pihak yang ingin dilayani. Pihak yang dilayani seyogyanya memahami keterbatasan dan kemampuan orang yang melayani, sehingga keterpaduan antara pihak yang melayani dan mendapat pelayanan memiliki perasaan yang sama.

Rumah sakit memiliki petugas yang peduli dengan pasien, ini terlihat dari hasil kuesioner dimana kemampuan dokter yang bertugas untuk menjawab semua pertanyaan-pertanyaan dan keluhan pasien (93,6\%), dokter memahami kebutuhan dan keluhan pasien $(84,2 \%)$ artinya pasien merasa diperhatikan dengan kemampuan dokter untuk menjawab semua pertanyaan-pertanyaan dan keluhan dari pasien. Peneliti menganggap faktor ini penting dalam meningkatkan loyalitas pasien terhadap RSUD Arosuka karena empati seorang dokter dapat menjadi obat bagi pasien.

\section{Hubungan Tampilan Fisik (Tangible) dengan Loyalitas Pasien}

Hasil penelitian hubungan tentang tampilan fisik dengan loyalitas pasien ditemukan ada hubungan yang bermakna antara tampilan fisik dengan loyalitas pasien. Berdasarkan persentase hasil sebaran data terlihat bahwa responden yang menyatakan tampilan fisik baik cenderung lebih loyal daripada responden yang menyatakan tampilan fisik rumah sakit yang kurang baik.

Hal ini sejalan dengan penelitian yang dilakukan Usep (2013) tentang pengaruh kualitas pelayanan dengan loyalitas pasien dimana terdapat hubungan yang bermakna antara bukti fisik dengan loyalitas pasien dengan nilai $p$-value 0,000 dan berbanding terbalik dengan penelitian yang dilakukan oleh Albori (2010) tentang faktor faktor yang mempengaruhi loyalitas pasien dimana tidak terdapat hubungan antara bukti fisik dengan loyalitas pasien.

Nursalam (2013) menyatakan bahwa wujud fisik yang baik akan mempengaruhi persepsi konsumen. Semakin bagus fasilitas fisik yang disediakan bagi konsumen maka semakin besar pula harapan konsumen pada pemberi jasa tersebut, selanjutnya ia menyatakan bahwa bukti fisik dalam kualitas layanan adalah bentuk aktualisasi nyata secara fisik dapat terlihat atau digunakan oleh pegawai sesuai dengan penggunaan dan pemanfaatannya yang dapat dirasakan membantu pelayanan yang diterima oleh orang yang menginginkan pelayanan, sehingga puas atas pelayanan yang diberikan.

\section{Hubungan Kehandalan (Reliability) dengan Loyalitas Pasien}

Hasil penelitian tentang hubungan kehandalan petugas dengan loyalitas pasien ditemukan ada hubungan yang bermakna antara kehandalan petugas dengan loyalitas pasien. Berdasarkan persentase hasil sebaran data terlihat kehandalan petugas yang baik cenderung lebih loyal daripada kehandalan petugas yang kurang baik.

Hal ini sesuai dengan penelitian Albori (2010) tentang faktor-faktor yang mempengaruhi loyalitas pasien dimana terdapat hubungan yang bermakna antara kehandalan dengan loyalitas pasien dengan nilai p-value 0,01 dan sejalan dengan penelitian yang dilakukan Usep (2013) tentang pengaruh kualitas pelayanan terhadap loyalitas pasien dengan nilai $p$ value 0,000 .

Kehandalan dalam penelitian ini merupakan penilaian pasien terhadap kemampuan rumah sakit dengan ketepatan waktu pelayanan, waktu untuk mengurus pendaftaran, waktu mulai pengobatan, waktu mengakhiri pengobatan, kesesuaian antara harapan dengan releasasi waktu bagi pasien.

Kehandalan merupakan penilaian kualitas pelayanan dilihat dari kemampuan rumah sakit yang berkaitan dengan ketepatan waktu pelayanan, waktu mengurus pendaftaran, waktu memulai pengobatan/pemeriksaan, kesesuaian antara harapan dan reliasisasi waktu bagi pasien (Herlambang, 2016).

\section{Hubungan Daya Tanggap (Respensiveness) dengan Loyalitas}

Hasil penelitian tentang hubungan daya tanggap dengan loyalitas pasien ditemukan ada hubungan yang bermakna antara daya tanggap dengan loyalitas pasien. Berdasarkan persentase hasil sebaran data terlihat daya tanggap yang baik cenderung lebih loyal daripada daya tanggap yang kurang baik.

Hal ini sesuai dengan penelitian yang dilakukan oleh Usep (2013) tentang pengaruh kualitas pelayanan terhadap loyalitas pasien dengan nilai $p$-value 0,020 dan berbading terbalik dengan penelitian yang dilakukan oleh Albori (2010) tentang faktor- faktor yang mempengaruhi loyalitas pasien dimana tidak terdapat hubungan yang bermakna antara daya tanggap dengan loyalitas pasien.

Secara teoritis penelitian ini sesuai dengan pendapat dari Gurunathan (2009) dalam Patwayati (2017) dimana dimensi pengukuran kualitas layanan yang diadopsi yakni diantaranya responsiveness mempunyai pengaruh terhadap loyalitas. Semakin tinggi responsiveness yang diberikan oleh pihak perusahaan jasa kepada pelanggan maka pelanggan akan loyal.

Hasil penelitian ini juga mendukung pendapat Parasuraman et al. (1994) dalam Kondasani (2015). Bahwa dimensi responsiveness berpengaruh terhadap tingkat loyalitas pasien cara petugas merespon keluhan dan masalah yang dihadapi pasien akan sangat menentukan loyalitas pasien. 


\section{Hubungan Jaminan (Assurance) dengan Loyalitas Pasien}

Hasil penelitian tentang hubungan jaminan dengan loyalitas pasien ditemukan ada hubungan yang bermakna antara jaminan dengan loyalitas pasien. Berdasarkan persentase hasil sebaran data terlihat bahwa jaminan petugas yang baik cenderung lebih loyal dibandingkan dengan jaminan petugas yang kurang baik.

Penelitian ini sesuai dengan penelitian yang dilakukan oleh Albori (2010) tentang faktor-faktor yang mempengaruhi loyalitas pasien dimana terdapat hubungan yang bermakna antara jaminan dengan loyalitas pasien dengan nilai $p$-value 0,01 dan sejalan dengan penelitian yang dilakukan Usep (2013) tentang pengaruh kualitas pelayanan terhadap loyalitas pasien dengan nilai $p$-value 0,002

Hasil penelitian ini sesuai dengan pendapat Parasuraman et al. dalam Kondasani (2015) yang menyimpulkan bahwa variabel Assurance yang termasuk kedalam dimensi kualitas pelayanan mempunyai hubungan dan pengaruh yang signifikan dengan variabel Loyalitas. Hal ini menunjukkan bahwa RSUD Aro Suka harus mampu memberikan jaminan bagi pelayanan kesehatan yang diberikan.

Berdasarkan hasil analisa peneliti, jaminan yang baik yang diberikan oleh rumah sakit akan mempengaruhi terbentuknya loyalitas pasien. Jaminan yang diberikan oleh rumah sakit seperti rumah sakit mempunyai tenaga medis dan non medis yang bisa dipercaya dan mempunyai kemampuan yang kompeten sesuai dengan bidangnya masing-masing akan membuat responden merasa yakin untuk memanfaatkan jasa pelayanan di rumah sakit tersebut. Jaminan yang baik akan menghilangkan keragu-raguan responden dalam mendapatkan pelayanan dan menimbulkan kepercayaan terhadap rumah sakit. Kepercayaan pasien berpengaruh signifikan dan positif terhadap loyalitas. Hal ini berarti jika penilaian pasien terhadap atribut kepercayaan yang terdiri dari: kemampuan layanan, integritas, menaruh harapan dan keterbukaan makin tinggi maka loyalitas pasien juga makin tinggi. Bendapudi, et al. (1997) dalam Djohan (2015) yang menyatakan bahwa trust sebagai salah satu landasan dedication based relationship yang menghasilkan working together, favorable recommendation dan advocacyserta. Pengalaman yang baik tentang jaminan yang didapatkan dari rumah sakit akan menyebabkan responden menceritakan yang baik-baik tentang rumah sakit ke orang lain sehingga membantu rumah sakit dalam melakukan promosi ke orang lain

\section{Hubungan Empati dengan Loyalitas Pasien}

Hasil penelitian tentang hubungan empati dengan loyalitas pasien ditemukan ada hubungan yang bermakna antara empati dengan loyalitas pasien. Berdasarkan persentase hasil sebaran data terlihat bahwa empati petugas yang baik cenderung lebih loyal dibandingkan dengan empati petugas yang kurang baik.

Hal ini sesuai dengan penelitian yang dilakukan Albori (2010) tentang faktor-faktor yang mempengaruhi loyalitas dengan nilai $p$-value 0,05 dan sejalan dengan penelitian yang dilakukan oleh Usep (2013) tentang pengaruh kualitas pelayanan terhadap loyalitas pasien dengan nilai $p$-value 0,000 .

Hasil penelitian ini mendukung pendapat Parasuraman et al dalam Kondasani (2015) yang menyimpulkan bahwa ada pengaruh positif antara dimensi empati (Emphaty) terhadap Loyalitas pasien. Hal ini menunjukkan bahwa di Poloklinik RSUD Aro Suka harus mampu memberikan perhatian penuh kepada pasien rawat jalan sehingga mempengaruhi secara positif terhadap loyalitas pasien.

Berdasarkan hasil analisa peneliti, empati yang diberikan oleh petugas rumah sakit berpengaruh dalam membentuk loyalitas pasien karena dengan adanya empati tersebut maka pasien merasa dihargai, merasa kalau rumah sakit dan petugas rumah sakit memahami apa yang dibutuhkannya saat ini, sehingga menimbulkan adanya kedekatan dengan rumah sakit sehingga mendukung terbentuknya loyalitas pasien. Dari hasil penelitian terdapat pasien empati baik tetapi tidak loyal terhadap rumah sakit, ini terjadi karena masih banyak faktor lain yang mempengaruhi terbentuknya loyalitas pasien.

\section{Faktor Dominan Kualitas Pelayanan Dimensi Servqual dengan Loyalitas Pasien}

Hasil uji statistik multivariat yang dilakukan peneliti diduga yang memiliki hubungan paling kuat dengan loyalitas adalah bukti fisik (tangibel) dengan nilai $p$-value $0,009<0,05$. Nilai OR yang diperoleh yaitu mempunyai peluang 2 kali menyebabkan pasien tidak loyal.

Sebagaimana telah disampaikan sebelumnya bahwa penelitian ini sesuai dengan penelitian yang dilakukan oleh Usep (2013) tentang pengaruh kualitas pelayanan dengan loyalitas pasien dimana bukti fisik dapat meningkatkan loyalitas pasien, sejalan dengan penelitian yang dilakukan oleh Yuni (2017) tentang pengaruh kualitas pelayanan terhadap loyalitas pasien rumah sakit Meloy di Sangata dimana variabel yang paling dominan adalah bukti fisik dan sesuai dengan pendapat Nursalam (2013) yang menyatakan bahwa wujud fisik yang baik akan mempengaruhi persepsi konsumen. Semakin bagus fasilitas fisik yang disediakan bagi konsumen maka semakin besar pula harapan konsumen pada pemberi jasa tersebut.

Penelitian ini juga sesuai dengan pendapat dari Gurunathan (2009) dalam Patwayati (2017) yang melihat dimensi pengukuran kualitas layanan yang diadopsi diantaranya yakni tangible mempunyai pengaruh terhadap loyalitas. Semakin tinggi kualitas layanan yang diberikan oleh pihak perusahaan jasa kepada pelanggan maka akan mempengaruhi keputusan pelanggan untuk memanfaatkan jasa tersebut, karena pelanggan yang puas terhadap layanan yang diberikan perusahaan akan melakukan pembelian ulang secara terus menerus sehingga akan menimbulkan perasaan loyalitas terhadap barang/jasa.

Berdasarkan hasil analisa peneliti bahwa dalam membentuk loyalitas pasien perlu memperbaiki penampakan dari bukti fisik rumah sakit, karena bukti fisik merupakan penilaian awal pasien dalam menentukan keputusan apakah akan membeli jasa atau mendapatkan pelayanan pada rumah sakit ini atau rumah sakit lain. Tentunya hal ini harus didukung oleh 
jaminan (assurance) yang diberikan oleh rumah sakit dan petugas rumah sakit kepada pasien. Jaminan yang diberikan oleh petugas kepada pasien akan menyebabkan hilangnya perasaan keragu-raguan dan menimbulkan rasa percaya terhadap tindakan dan pelayanan jasa yang diberikan oleh petugas rumah sakit. serta perilaku empati yang diberikan oleh petugas rumah sakit dalam memberikan pelayanan kepada pasien.

\section{SIMPULAN}

1. Lebih dari separuh responden tidak memiliki loyalitas di Poliklinik RSUD Arosuka Tahun 2018.

2. Lebih dari separuh responden menyatakan bahwa tampilan fisik (tangible) rumah sakit kurang baik di Poliklinik RSUD Arosuka Tahun 2018

3. Hampir separuh responden yang berkunjung menyatakan bahwa kehandalan (reliability) petugas kurang baik di Poliklinik RSUD Arosuka Tahun 2018.

4. Lebih dari separuh responden yang berkunjung menyatakan bahwa daya tanggap (responsivenes) dari petugas kurang baik di Poliklinik RSUD Arosuka Tahun 2018

5. Hampir separoh dari responden yang berkunjung menyatakan bahwa jaminan (assurance) kurang baik di Poliklinik RSUD Aro Suka Tahun 2018.

6. Hampir separuh dari responden yang berkunjung menyatakan bahwa empati (empathy) petugas kurang baik di Poliklinik RSUD Arosuka Tahun 2018.

7. Terdapat hubungan yang bermakna antara tampilan fisik (tangible) dengan loyalitas pasien di Poliklinik RSUD Arosuka

8. Terdapat hubungan yang bermakna antara kehandalan (reliability) dengan loyalitas pasien di Poliklinik RSUD Arosuka.

9. Terdapat hubungan yang bermakna antara daya tanggap (responsivenes) dengan loyalitas pasien di Poliklinik RSUD Arosuka

10.Terdapat hubungan yang bermakna antara jaminan (assurance) dengan loyalitas pasien di Poliklinik RSUD Arosuka

11.Terdapat hubungan yang bermakna antara empati (empathy) dengan loyalitas pasien di Poliklinik RSUD Arosuka

12. Terdapat hubungan yang paling dominan bermakna antara bukti fisik (tangible) dengan loyalitas pasien di poliklinik RSUD Arosuka

\section{Saran}

\section{Bagi Manajemen Rumah Sakit}

a. Direktur membuat kebijakan tentang jam pelayanan yang harus disepakati untuk dilaksanakan secara bersama.

b. Direktur memotivasi semua petugas rumah sakit untuk mentaati jam pelayanan yang telah disepakati

c. Direktur membuat kebijakan tentang sanksi bagi petugas yang masuk tidak tepat waktu

d. Direktur berkoordinasi dengan pemerintah daerah untuk pengadaan transportasi umum untuk pasien ke rumah sakit.

e. Kepala bidang pelayanan membicarakan jam mulai pelayanan di poliklinik dengan dokter spesialis supaya bisa datang tepat waktu sesuai dengan jadwal poliklinik.

f. Kepala bidang penunjang mendesain ruang tunggu yang nyaman, menambah jumlah kursi di ruang tunggu, menyediakan pojok informasi atau ruang konsultasi misalkan konsultasi gizi disaat waktu tunggu, menyediakan televisi yang menampilkan program program hidup sehat misalnya diet hipertensi dan lain-lain.

g. Kepala seksi keperawatan berkoordinasi dengan kepala ruangan untuk memberikan pengarahan kepada perawat di masing-masing ruangan untuk bersikap sopan, ramah, dan membina hubungan yang baik dengan pasien. Memotivasi perawat masing-masing ruangan agar menjelaskan semua tindakan atau kegiatan pelayanan yang akan diterima oleh pasien.

h. Kepala bidang pelayanan menyediakan kotak surat sebagai tempat untuk menerima keluhan pasien sehingga bisa dijadikan sebagai evaluasi diri bagi pelayanan rumah sakit ke depannya.

\section{Bagi Petugas Rumah Sakit}

a. Petugas pendaftaran tetap datang sesuai dengan jadwal buka pelayanan dan langsung memberikan pelayanan kepada responden

b. Dokter memberikan waktu bagi pasien untuk bertanya atau konsultasi tentang masalah kesehatan pasien yang belum dipahami pasien.

c. Dokter spesialis yang sudah lengkap 2 orang sebaiknya dibagi untuk melakukan visite ruangan dan melayani poliklinik sehingga pelayanan bisa jalan sesuai dengan jadwal pelayanan.

d. Perawat menginformasikan kepada pasien jam mulai pelayanan dan selesai pelayanan

e. Perawat mengkomunikasikan semua tindakan keperawatan atau pelayanan yang akan diterima oleh responden.

\section{Bagi Institusi Pendidikan}

Hasil penelitian dapat dijadikan sebagai referensi bahwa loyalitas sangat diperlukan untuk keberhasilan suatu perusahaan atau instansi untuk mencapai kesuksesan.

\section{Bagi Penelitian}

a. Peneliti lebih memahami lagi bahwa untuk meningkatkan kunjungan bukan hanya memperhatikan kepuasan tetapi yang terpenting adalah loyalitas, sehingga peneliti dapat memanfaatkan hasil penelitian ini setelah kembali ke instansi rumah sakit.

b. Bagi peneliti selanjutnya, agar dapat melanjutkan penelitian ini dengan melihat faktor-faktor lain yang berhubungan dengan loyalitas pasien

\section{DAFTAR PUSTAKA}

Alimul H,Azis. (2009). Metode penelitian dan Teknik Analisa Data. Jakarta: Salemba Medika.

Aryani Dwi. (2010). Pengaruh Kualitas Layanan terhadap Kepuasan Pelanggan dalam Membentuk Loyalitas Pelanggan.17:114-126.

Albori A, Ghani SN, Yadav H, Daher AM, Su TT.(2010).Patient satisfaction and loyalty to the private hospital in Sana'a, Yemen. Int J Qual Heal Care. .22(4):1-6. 
Amin M, Zahora Nasharuddin S. (2013). Hospital service quality and its effects on patient satisfaction and behavioural intention. Clin Gov An Int J. 18(3):238-254. doi:10.1108/CGIJ-05-2012-0016.

Al-Borie, M, Hussein. (2011). Patients satisfaction of service quality in Saudi hospital: a SERVQUAL analysis. International Journal of Health Care Quality Assurence. Vol 26. No 1. 20-30.

Baloglu S. (2002)Dimensions of customer loyalty: separating friends from well wishers. Cornell Hotel Restaur Adm Q. 43(1):47-59. doi:10.1016/S00108804(02)80008-8.

Bei L, Chiao Y.(2006). The determinants of customer loyalty: An analysis of intangible factors in three service industries. Int $\mathrm{J}$ Commer Manag. 16(3/4):162-177. doi:10.1108/10569210680000215.

Bobocea, Gheorghe. (2016) . The management of health care service quality physician perspective. Journal of medicine and life. Vol 9. 149-152.

Cronin JJ, Brady MK, Hult GTM. (2000).Assessing the effects of quality, value, and customer satisfaction on consumer behavioral intentions in service environments. J Retail. 76(2):193-218. doi:10.1016/S0022-4359(00)00028

Chakraborty R, Majumdar A. (2011).Measuring Consumer Satisfaction In Health Care Sector: The Applicability Of Servqual. J Arts:2231-4172.

Caruana A. (2002)Service loyalty. Eur J Mark. 36(7/8):811-828.

doi:10.1108/03090560210430818.

Delgado-Ballester E, Luis Munuera-Alemán J. (2001).Brand trust in the context of consumer loyalty. Eur J Mark. 35(11/12):1238-1258. doi:10.1108/EUM0000000006475

Djohan AJ. (2015). Faktor-Faktor yang Mempengaruhi Kepuasan dan Kepercayaan untuk Mencapai Loyalitas Pasien Rawat Inap pada Rumah Sakit Swasta di Kota Banjarmasin. (66):257-271.

Fitri,Najmah. (2016). Hubungan Kualitas Pelayanan Dengan Loyalitas Pasien di Instalasi Rawat Jalan Rumah Sakit Khusus Mata Provinsi Sumatera Selatan. Volume 7 No1

Griffin, Jill. (2003). Customer Loyalty: Menumbuhkan dan Mempertahankan Kesetiaan Pelanggan. Erlangga.

Gunawan. (2011). Kualitas Layanan Dan Loyalitas Pasien. Volume 13. No 1: 32-39

Herlambang, Susatyo. (2016). Manajemen Pelayanan Kesehatan Rumah Sakit. Yogyakarta.

Hajikhani, Shadi. (2016). The relationship between the customer relationship management and patients loyalty to hospital. Global Journal of Health Science. 65-71.

Imroatul, Khasanah. (2010) . Analisis pengaruh Kualitas Pelayanan Terhadap Kepuasan Konsumen RS St Elisabeth Semarang.Universitas Diponegoro. ISSN: 1693-928x

Kandampully J, Suhartanto D. (2000).Customer loyalty in the hotel industry: the role of customer satisfaction and image. Int $J$ Contemp Hosp Manag. 12(6):346-351.
Kondasani RKR, Panda RK. (2015).Customer perceived service quality, satisfaction and loyalty in Indian private healthcare.Int $J$ Health Care Qual Assur. 28(5):452-467. doi:10.1108/IJHCQA-01-20150008.

Kotler,Philip. (2001) .Managemen Pemasaran: Analisis, Perencanaan, Implementasi dan kontrol.Jakarta: PT.Prehallindo.

Lonial S, Menezes D, Tarim M, Tatoglu E, Zaim S. (2010)An evaluation of SERVQUAL and patient loyalty in an emerging country context.Total Qual Manag Bus Excell. 21(8):813-827. doi:10.1080/14783363.2010.487663.

Ladhari R, Souiden N, Ladhari I. (2011). Determinants of loyalty and recommendation: The role of perceived service quality, emotional satisfaction and image. J Financ Serv Mark.16(2):111-124. doi:10.1057/fsm.2011.10

Lubis,Arlina. (2009). Pengaruh Consumer Education Dan Service Quality Terhadap Kepuasan Dan Loyalitas Pasien Rawat Inap (Studi Pada Rumah Sakit Umum Swasta di Kota Medan. Volume 7. No2

Marquis, Bessie.(2010). Kepemimpinan dan Manajemen Keperawatan: Teori Dan Aplikasi. Jakarta: EGC.

Mohd Suki.(2011). Assessing patient satisfaction, trust, commitment, loyalty and doctors reputation towards doctors services.Pakistan Journal of Medical Sciences. http://www.pjms.com.pk/index.php/pjms/article/vie w/1508/346. Accessed October 29, 2017.

Najmah, Fitri. (2016). Hubungan Kualitas Pelayanan Dengan Loyalitas Pasien di Instalasi Rawat Jalan Rumah Sakit Khusus Mata Propinsi Sumatera Selatan. Universitas Sriwijaya.

Nursalam. (2013). Metode Penelitian IImu Keperawatan. Edisi ketiga. Jakarta: Salemba Medika

Nekoei-moghadam M, Amiresmaili M. (2011).Hospital services quality assessment Hospitals of Kerman University of Medical. 24(1):57-66. doi:10.1108/09526861111098247.

Putra I, Katili PB, Arina F. (2013). Pengaruh Kualitas Pelayanan Terhadap Persepsi Dan Kepuasan Pasien dalam Meningkatkan Loyalitas Pasien. $1(1): 41-47$.

Parasuraman A. (2010). Service productivity, quality and innovation. Int J Qual Serv Sci. 2010;2(3):277286. doi:10.1108/17566691011090026.

Patwayati. (2017).Analisis Pengaruh Kualitas Layanan Terhadap Kepuasan Dan Loyalitas Pasien (Studi Pada Laboratorium Rumah Sakit Umum Daerah Kota Kendari). Universitas Halu Oleo. ISSN:12345678-90

Pradana, Alif. (2014). Hubungan lama waktu tunggu dengan persepsi klien terhadap loyalitas di instalasi rawat jalan rumah sakit Jatinegoro Lumajang . Diakses melalui http://www.google.com/search/client.pdf pada tanggal 20 Mei 2018

Pricilya. (2017). Faktor-faktor Yang Berhubungan Dengan Loyalitas Pelanggan Di Instalasi Rawat Jalan Rumah Sakit Umum Pusat Prof. Dr. R. D. Kandou

manado. 
Diaksesmelalui.http://ejournalhealth.com/index.ph $\mathrm{p} / \mathrm{CH} /$ article/viewfile/610/598/pdf pada tanggal 2 Juni 2018

Riduwan, (2014). Metode dan Teknik Menyusun tesis. Bandung:Alfabeta

Sirdeshmukh D, Singh J, Sabol B. (2002). Consumer Trust, Value, and Loyalty in Relational Exchanges.J Mark. 66(1):15-37. doi:10.1509/jmkg.66.1.15.18449.

Sumantri,Arif. (2011) .Metodologi Penelitian Kesehatan. Edisi pertama. Jakarta: Kencana

Sugiyono. (2001). Metode Penelitian Administrasi. Bandung: Alfabeta.

Triwibowo. (2013). Manajemen Pelayanan Keperawatan. Jakarta.

Tjitono, Fandy. (2003). Total Quality Management (TQM). Yogyakarta.

(2012). Service Management Mewujudkan Pelayanan Prima. Yogyakarta: Andi Offset Yogyakarta: Andi Offset.

Usep. (2015). Pengaruh Kualitas pelayanan Terhadap loyalitas Pasien di Rumah Sakit Islam Sultan Agung Semarang. Diakses melalui Eprints.dinus.ac.id/17285/1/jurnal.16413.pdf. pada tanggal 2 Juni 2018.

Wadji. (2015). Faktor-Faktor Yang Berpengaruh Pada Loyalitas Pelanggan Klinik Saraf Rumah Sakit Jiwa Daerah Dr R.M. Soedjarwadi. Volume 17. no 17.

Yuni,Thimang. (2017). Pengaruh Kualitas Pelayanan Terhadap Loyalitas Pasien Rumah Sakit Meloy di Sangtta. ISSN: 2355-5408

Zarei A, Arab M, Froushani AR, Rashidian A, Ghazi Tabatabaei SM. (2012). Service quality of private hospitals: The Iranian Patients' perspective. BMC Health Serv Res. 12(1):31. doi:10.1186/14726963-12-31.

Zeithaml VA, Parasuraman A, Malhotra A. (2002).Service Quality Delivery through Web Sites: A Critical Review of Extant Knowledge. J Acad Mark Sci. 30(4):362-375. doi:10.1177/009207002236911. 